\title{
Introduction of management innovations in the work of municipal organizations
}

\author{
Tatiana Averina ${ }^{1, *}$, Elena Avdeeva ${ }^{1}$, Olga Perevalova ${ }^{1}$ \\ ${ }^{1}$ Voronezh State Technical University, Moscow Avenue, 14, Voronezh, 394026, Russia
}

\begin{abstract}
Personnel management is recognized as one of the most important ways to improve the competitiveness of the organization in the local and national market. In the modern world, the life cycle of knowledge is becoming shorter, which requires regular updating of professional knowledge and abilities. Continuous updating of knowledge and improvement of skills are obligatory conditions for success. The most important task of enterprises of different forms of ownership is to increase the attractiveness of jobs in the regions for highly skilled professionals, to achieve high efficiency of employees through the improvement of personnel management systems. Management innovation is a universal tool for modernizing management. SWOT-analysis of the personnel management system of the Department of Property and Land Relations of the Voronezh Region made it possible to identify its strengths and weaknesses. The proposed innovative forms of management: career maps, employee development maps and scoring system are estimated using the models of D. Kirkpatrick and D. Phillips. Based on the analysis of trajectories of innovative development, the optimal moment for introducing changes and changing the development trajectory is determined. Assessment of the socio-economic impact of the implementation of measures confirmed their necessity and inevitability in the real economy.
\end{abstract}

\section{Introduction}

Any organization needs employees who possess modern knowledge and technologies which can effectively apply them in practice. But to have such employees worked in the organization, it is necessary to create an effective personnel management system and constantly improve it. A number of researchers recognize personnel management as one of the most important aspects of organization life, able to significantly improve its efficiency. The concept of "personnel management" is considered in broad terms: from economic and statistical to philosophical and psychological. The topic is covered in the works of Russian and foreign researchers [1].

\footnotetext{
*Corresponding author: ta_averina@mail.ru
} 
Increasing the attractiveness of municipal service in the regions for highly qualified specialists, achieving the efficiency of municipal employees in the regions through the improvement of personnel management systems is the most important task.

The subject of the research is the personnel management system in the Department of Property and Land Relations of the Voronezh Region, Russia.

The objective of the current study is to develop management innovations which will improve the personnel management system in the Department of Property and Land Relations of the Voronezh Region.

\section{Materials and Methods}

The urgency of changes and innovations is caused by the need to adapt the municipal organization to the requirements of the external and internal environment, to acquire new knowledge and technologies, which is an important condition in the market economy. The amount of knowledge possessed by mankind is constantly growing, and the number of new situations which requires an adequate solution is increasing. So the importance of transformation management tasks is increasing too. The purpose of such changes is the implementation of progressive transformations to transfer the organization to a highly effective state $[2,3]$.

The reasons for organizational changes and innovations can be economic, organizational, ideological, human resources, information. The most common are: changes in the external working conditions (the actions of competitors), the emergence of advanced technologies for solving management problems (automation and computerization), bureaucratization of the management apparatus (increase in management costs).

The main properties of innovative changes are presented in Fig. 1.

\section{Innovation properties}

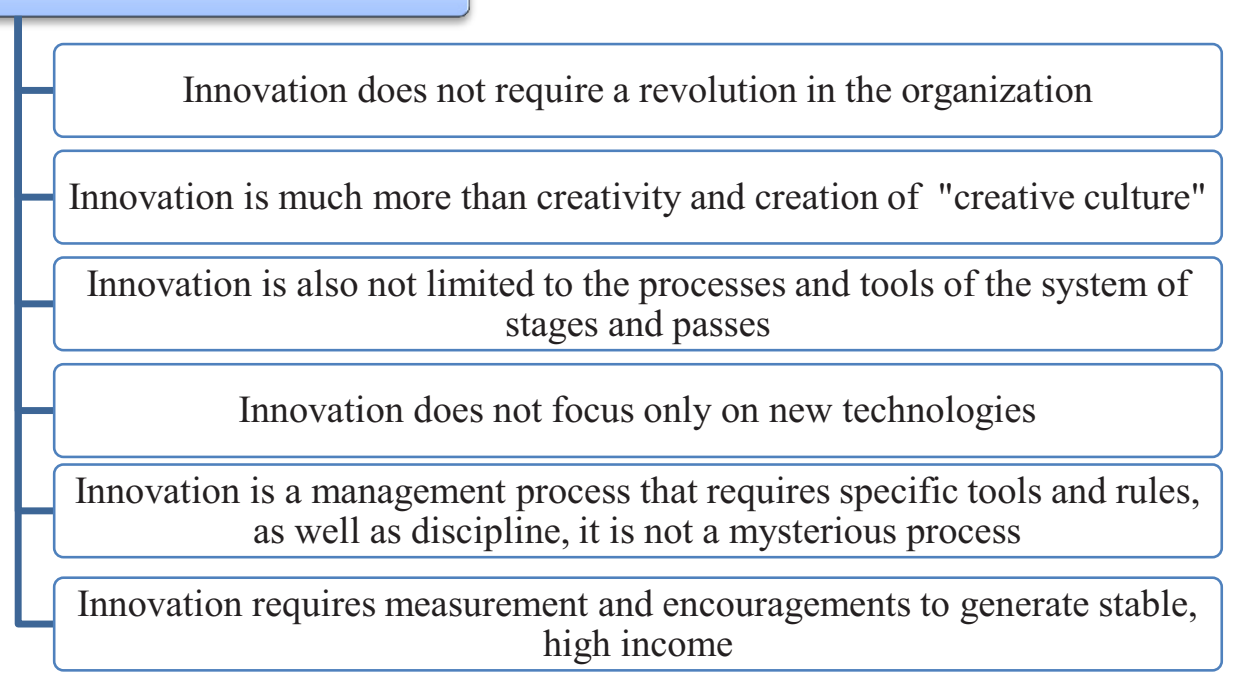

Fig. 1. Main properties of innovations.

The technology of personnel management involves the organization of recruitment, selection, hiring, its business evaluation, career guidance and adaptation, management of its business career and professional promotion, training, management of conflicts and stresses, motivation and organization of work, ensuring the social development of the organization, 
the release of staff and more. It should also include the issues of interaction between managers of the organization with the employment services and trade unions, personnel security management.

Management innovation refers to any purposeful change in management technology aimed at replacing the existing management mechanism or its elements in order to accelerate, facilitate or improve the achievement of identified targets [4].

In general, management innovations are much cheaper and more profitable than technical ones, as they are not associated with the purchase of expensive equipment and technologies and do not require investment. However, the consequences of management innovation are less predictable than those of technical and technological innovation. Features of management innovations are presented in Fig. 2.

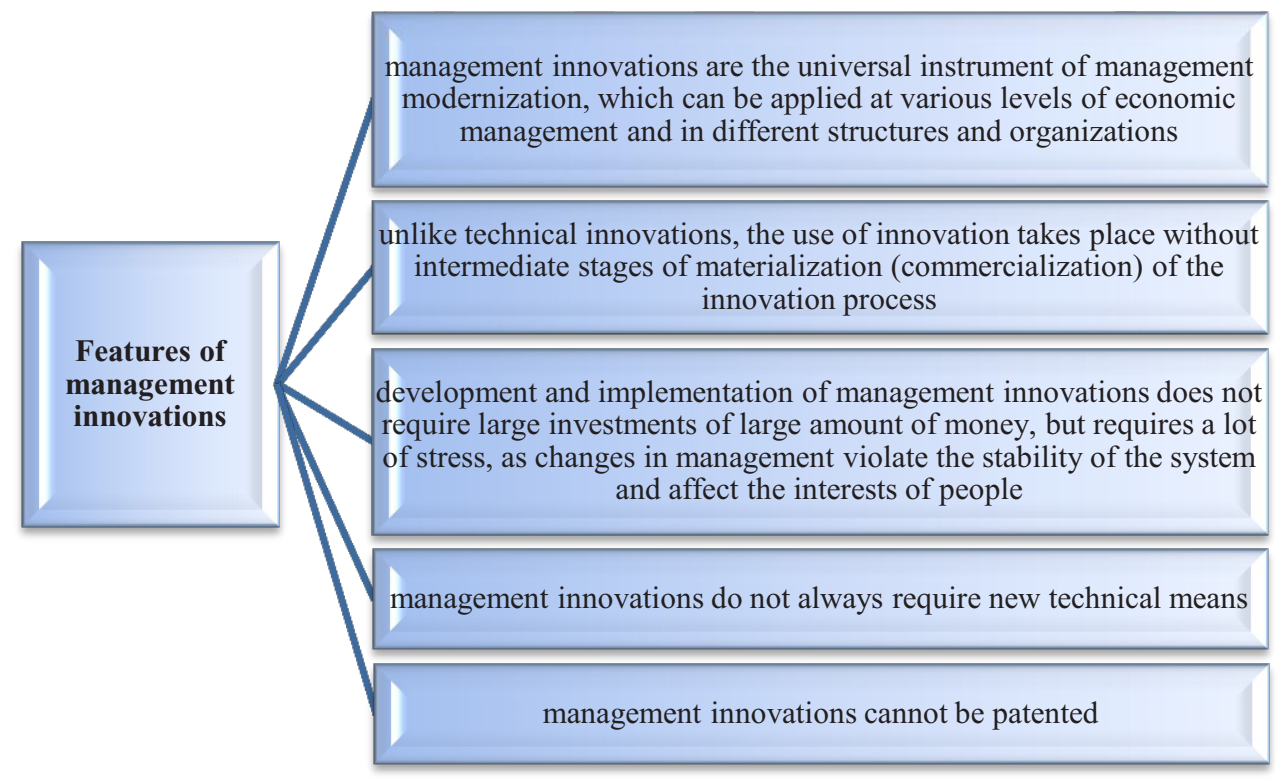

Fig. 2. Features of management innovations.

SWOT analysis of the personnel management system of the Department of Property and Land Relations of the Voronezh Region is given in Table $1[5,6]$.

Based on the analysis, it was found that the Department has the following problems:

- employees practically can't impact on wage as its size is defined and fixed;

- there is a large number of tasks before employees, and, as a consequence, not always the implementation of the plan on time due to the absence of ranking system;

- lack of monitoring of employees ' opinions on incentives;

- the influence of interpersonal relationships on the distribution of rewards, etc.

That is why it is necessary to develop its own incentive system, since in order to achieve the Department's objectives, every employee must make every effort.

Table 1. SWOT analysis of the personnel management system of the Department of Property and Land Relations of the Voronezh Region. 


\begin{tabular}{|c|c|c|}
\hline External & $\begin{array}{l}\quad \text { Opportunities } \\
\text { - the possibility of distance } \\
\text { education; } \\
\text { - cooperation with higher } \\
\text { education institutions for staff } \\
\text { development; } \\
\text { - development of information } \\
\text { technology }\end{array}$ & $\begin{array}{l}\quad \text { Threats } \\
\text { - dependence on } \\
\text { information technology; } \\
\text { - shortage of qualified and } \\
\text { experienced personnel; } \\
\text { - high average age of the } \\
\text { staff; } \\
\text { - constantly changing } \\
\text { legislation }\end{array}$ \\
\hline $\begin{array}{l}\text { Strengths } \\
\text { - high qualified personnel and } \\
\text { extensive experience; } \\
\text { - technical support of the work } \\
\text { process; } \\
\text { - regular staff development; } \\
\text { - availability of its own website; } \\
\text { - convenient location (city } \\
\text { center); } \\
\text { - all activities are regulated at } \\
\text { the legislative level }\end{array}$ & $\begin{array}{l}\text { - thanks to the system of distance } \\
\text { education staff has the opportunity } \\
\text { to regularly improve their skills } \\
\text { without interrupting the work } \\
\text { process; } \\
\text { - thanks to the cooperation with } \\
\text { institutions of higher education } \\
\text { employees are constantly } \\
\text { improving their skills; } \\
\text { - thanks to the development of } \\
\text { information technology simplifies } \\
\text { the workflow }\end{array}$ & $\begin{array}{l}\text {-regular staff development } \\
\text { contributes to the } \\
\text { acquisition of new } \\
\text { knowledge, which has a } \\
\text { positive impact on the } \\
\text { workflow; } \\
\text { - on the website it is } \\
\text { possible to place } \\
\text { information about } \\
\text { vacancies that promotes } \\
\text { the fastest search of new } \\
\text { employees }\end{array}$ \\
\hline $\begin{array}{l}\text { Weaknesses } \\
\text { - lack of high motivation among } \\
\text { employees; } \\
\text { - a large number of paper } \\
\text { documents; } \\
\text { - high level of workload; } \\
\text { - insufficient information of the } \\
\text { employee about the } \\
\text { opportunities for career growth; } \\
\text { - bureaucratization }\end{array}$ & $\begin{array}{l}\text { - changes in legislation can have a } \\
\text { beneficial effect on staff } \\
\text { motivation; } \\
\text { - thanks to the use of modern } \\
\text { information technologies and the } \\
\text { experience of scientists in the field } \\
\text { of management, it is possible to } \\
\text { create modern tools for visual } \\
\text { motivation of employees in the } \\
\text { form of career cards and } \\
\text { development maps; } \\
\text { - reduction the number of paper } \\
\text { through the use of information } \\
\text { technology }\end{array}$ & $\begin{array}{l}\text { - changing the legislation } \\
\text { to some extent may } \\
\text { adversely affect workers } \\
\text { or potential employees; } \\
\text { - it is more difficult to } \\
\text { learn new information } \\
\text { technologies for middle- } \\
\text { aged employees; } \\
\text { - lack of high motivation } \\
\text { of employees can affect } \\
\text { the results of the work } \\
\text { process throughout the } \\
\text { organization; } \\
\text { - the workflow is highly } \\
\text { dependent on technical } \\
\text { support. }\end{array}$ \\
\hline
\end{tabular}

\section{Results}

A career card is a tool for motivating employees, which visually displays the possible options for vertical and horizontal movements of civil servants along the job ladder.

The career card includes:

- the list of the Department's posts distributed according to the level of hierarchy and management;

- the competencies corresponding to each position: professional; personal; general (general professional and general cultural) competences.

The employee development map is based on the career card. It prescribes the competencies required for a particular position, as well as a plan of activities for their development. The activities can offer both the department and the employee himself to show personal initiative in this field. The development map provides an opportunity to 
analyze the elements of the system in order to determine the achieved competencies and form a training plan for a certain period. It reflects the necessary competencies and skills of the employee, who applies for a position or is already on it. Then a success sheet is compiled as a register of employee achievements in the current position. It is the basis for a conversation about the career of an employee and leader.

The main measures for introducing a scoring system are shown in Fig. 3.

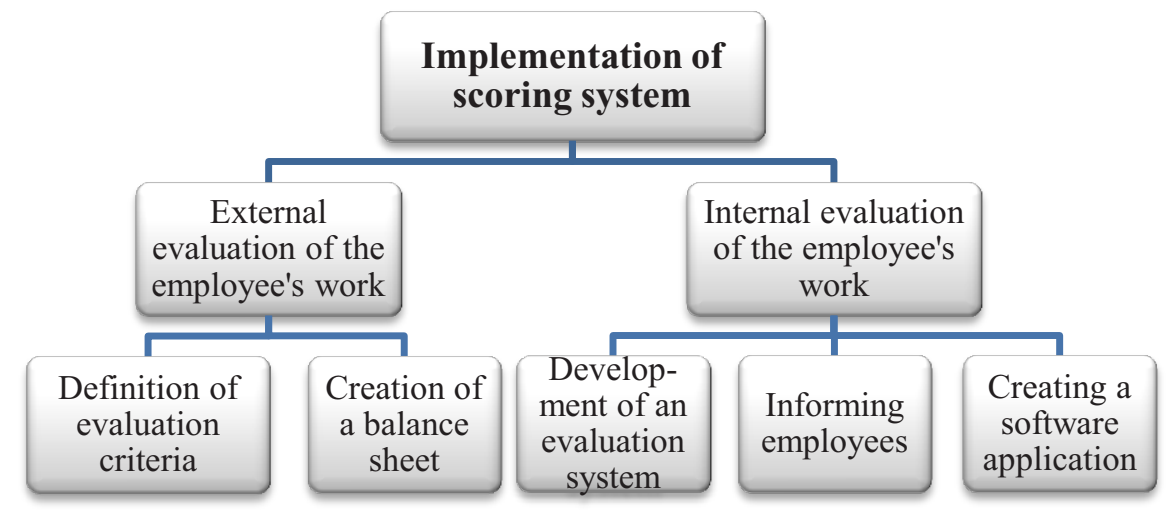

Fig. 3. Main measures for introducing a scoring system.

To evaluate the actions implemented in the personnel management system, various methods which are recognized by the world community can be used. In this case, we use the model of James D. Kirkpatrick and Wendy Kayser Kirkpatrick and the model of Jack Phillips.

The Kirkpatrick [7] model is one of the most well-known ways of assessing the effectiveness of various management programs. The model consists of four levels:

Level 1 - this level reflects the emotional response of participants to the proposed actions.

Level 2 - there is an assessment of the opinions of employees regarding the specificity of the proposed actions.

Level 3 - the level indicates the success of these actions.

Level 4 - determine the results of actions and analyze the changes that have occurred in the behavior or skills of employees. An assessment of this level can become the basis for making management decisions about the rationality of holding similar actions in the future.

An analysis based on the Kirkpatrick model can help in the following:

- draw conclusions about whether it is worth to introduce these actions and how to improve them in the future;

- Collect material to improve the proposed innovations;

- Evaluate the contribution of actions to the improvement of the process of personnel management.

The results of the evaluation of the proposed actions for each of the levels are shown in Fig. 4. The evaluation is carried out according to the scoring scale, which is presented in Table. 2 . 


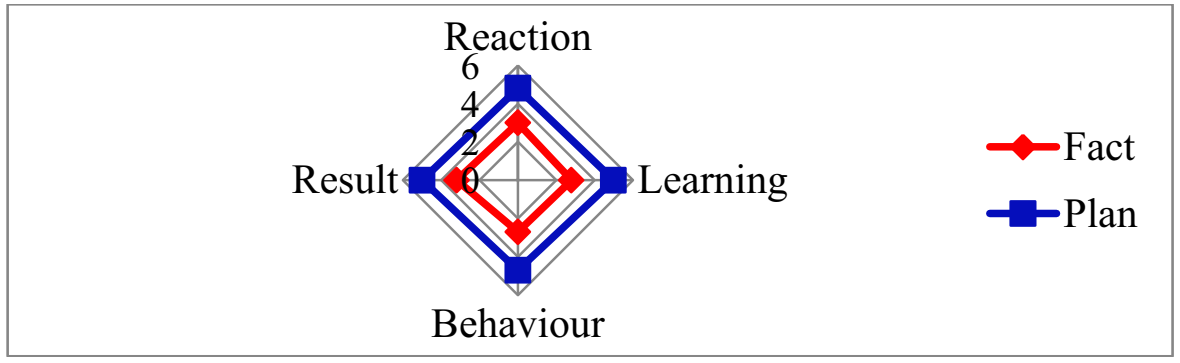

Fig. 4. The results of the evaluation of the proposed actions.

Table. 2. Scoring Scale.

\begin{tabular}{|c|l|}
\hline Scoring Scale & Evaluation Meaning \\
\hline 1 & Completely dissatisfy \\
\hline 2 & Rather does not satisfy \\
\hline 3 & Can not say \\
\hline 4 & Rather satisfies than not \\
\hline 5 & Completely satisfies \\
\hline
\end{tabular}

Jack Phillips added a fifth rating level to the model of Donald Kirkpatrick, which is called "Return on Investment (ROI)." Recently, this indicator has become the universal tool and shows whether investments in any activities in the field of personnel management can be recouped.

It is considered that the calculation of ROI will help HR managers to obtain a large amount of benefits:

- assess the financial efficiency of various management actions in monetary terms;

- present the results of work to the head in the adopted terms of figures;

- get the universal, understandable and reliable tool that can identify successful or, conversely, ineffective programs.

Despite the simplicity of the ROI calculation formula, it takes a lot of time to calculate the return on investment.

Calculation of the actions efficiency and the impact of their implementation is made by the following formula:

$$
\mathrm{ROI}=(\text { Revenue }- \text { Costs }) /(\text { Costs }) * 100 \%
$$

To estimate the costs of proposed activities, it is necessary to make a list of costs for their implementation.

A set of indicators for quantifying the workforce of organization can be divided into several groups. The first group of indicators assesses performance-it is the added value per employee. The second group characterizes unforeseen costs caused by low qualification: quit and absence from work, accidents, defect in work and decrease of quality. The third group is indicators of qualification and quality of the estimated group of people.

In the modern world, the life cycle of knowledge is becoming shorter, which requires regular updating of professional knowledge and abilities. Continuous education means the renewal of knowledge and the increase of education, which gradually blurs the line between basic and further education. Thus, education has become a vital factor for maintenance the effective productivity of institutions and organizations and a factor that stimulates management personnel to introduce innovative methods of work. They do not give an instant effect, but they are effective in the future according to the opinion of the leaders of the largest corporations. 
At the same time, it is important to study and analyze the parameters of innovative development trajectories in order to determine the optimal time for introducing changes, i.e. change of the trajectory of innovative development.

The trajectory of innovation development can be defined in several ways:

Straight line of development:

$$
y=y_{0}+a \cdot t
$$
time.

It is preferable for describing the functional characteristics, evenly developing over

The exponential development curve:

$$
y=y_{0} \cdot e^{k \cdot t}
$$

It well shows an avalanche growth when the gain depends mainly on the level achieved. If, together with the increase in the level reached, the effect of the limiting factor increases, then a good description of this process can be obtained with the use of a modified exponential [8]:

$$
y=L-\left(L-y_{0}\right) \cdot e^{-k \cdot t}
$$

The following form of the exponential curve can be used [9]:

$$
x=Q_{i}+\left(x_{0}-Q_{i}\right) \cdot e^{-\beta \cdot t}
$$

Namely, we give the general form of the exponential trajectory in the following form:

$$
x_{i}(t)=x_{k_{i}}+\left(x_{0_{i}}-x_{k_{i}}\right) \cdot e^{-k_{i} \cdot x_{0_{i}} \cdot u_{i} \cdot t}
$$

$k_{i}$ is a certain constant; $u_{i}$ - the value of the resource parameter along trajectory;

$x_{0_{i}}$ - the value of the trajectory at the initial time; $x_{k_{i}}$ is the final value of the trajectory.

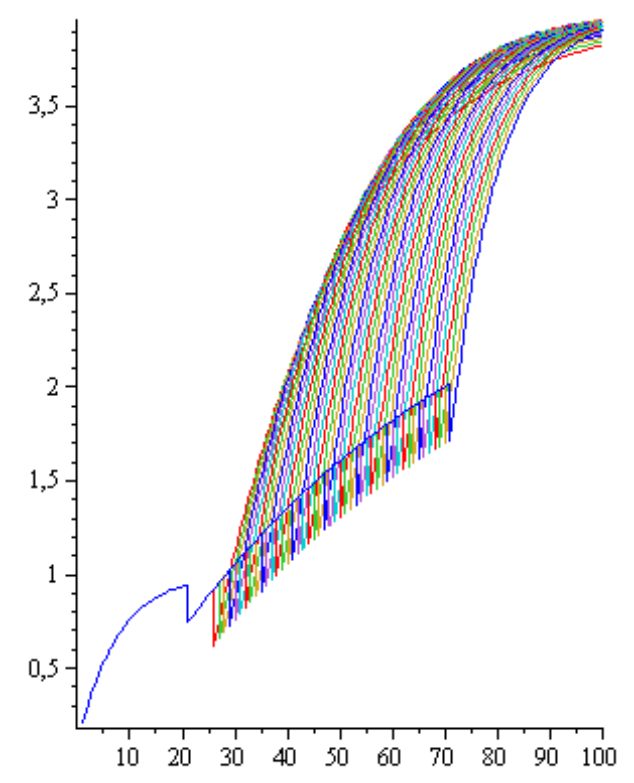

Fig. 5. Variations of trajectories for various transition points for given parameters. 
According to V.V. Glukhov and M.E. Oseevsky [8] if the limiting factor begins to affect only after a certain moment, the S-shaped curves (Pearl, Gompertz, etc.) give the best approximation.

The S-shaped trajectory of development began to be used at the beginning of the 19th century to describe the development of different processes.

In processes which at first grow slowly, then accelerate, and then again slow down the growth, reaching to any limit, are rather widespread in economy. To simulate such processes the so-called S-shaped curves are used. The slope of the curve and the turning points of development in each period of time reflect the effectiveness of innovation and the degree of potential utilization. As we approach the limit, further improvement of this innovation becomes economically inexpedient.

Let's consider some mathematical ways of specifying S-shaped curves in more detail.

1. The logistic curve, or the Pearl-Read curve, is an increasing function, most often expressed as:

$$
Y_{t}=\frac{k}{1+a \cdot e^{-b t}}
$$

Other types of this curve:

$$
Y_{t}=\frac{k}{1+a^{-b t}} ; \quad Y_{t}=\frac{k}{1+10^{a-b t}} .
$$

In these expressions, $a$ and $b$ are positive parameters;

$k$ is the limiting value of the function with an infinite increase in time.

The logistic curve has a symmetry point coinciding with the inflection point [4].

2. As a modification of the functions of the hyperbolic tangent or the function of the arctangent. Figures 6 and 7 show the families of the corresponding curves.

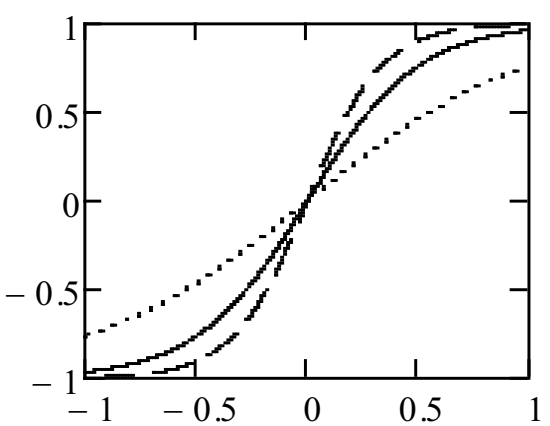

Fig. 6. Family of functions of hyperbolic tangent.

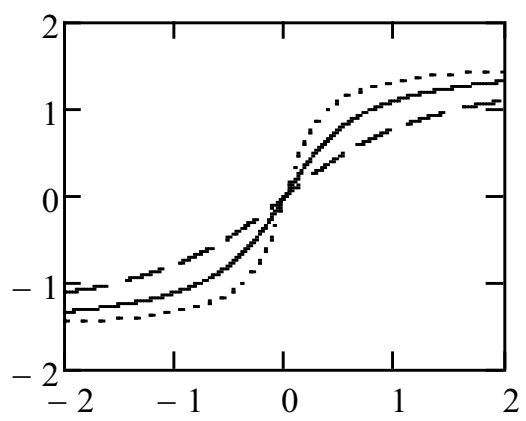

Fig.7. The family of arctangent functions.

We define the modified tangent and arctangent functions in the form [10]:

$$
\begin{aligned}
& x(t)=x_{0}+\left(x_{k}-x_{0}\right)\left(\frac{t h((t-a) \beta)}{2}+\frac{1}{2}\right), \\
& x(t)=x_{0}+\left(x_{k}-x_{0}\right) \frac{\left(\operatorname{arctg}((t-a) \cdot \pi \cdot \beta)+\frac{\pi}{2}\right.}{\pi}
\end{aligned}
$$

where $x_{0}$ is the value of the trajectory at the initial instant of time; $x_{k}$ - the value of the trajectory at the end of the time period; $\beta$-parameter characterizing the curve growth rate, $a$ - displacement (for $a=\frac{1}{2}$ the curve is symmetric). 
This method of specifying curves allows us to describe the processes of consecutive change of trajectories with different characteristics, which is especially important in the conditions of innovative development.

The issues related to determining the optimal time for the transition to a new trajectory of innovative development by criterion - the highest average economic efficiency for the studied time period were considered in detail in $[5,10,11]$.

Besides, implementation of the proposed activities can receive a positive social effect [12]. The main social results from the implementation of the proposed activities to improve the management system Personnel in the Department of Property and Land of the Voronezh Region are presented in Table. 3.

Table 3. Social effect.

\begin{tabular}{|c|c|c|}
\hline Actions & Social Results & Performance Indicators \\
\hline \multirow{5}{*}{$\begin{array}{c}\text { Career } \\
\text { cards, } \\
\text { development } \\
\text { maps }\end{array}$} & $\begin{array}{l}\text { Realization and development of } \\
\text { individual abilities of employees, } \\
\text { personal and professional } \\
\text { competences }\end{array}$ & \multirow{5}{*}{$\begin{array}{l}\text { - increase in the proportion of employees } \\
\text { seeking to improve their skills, } \\
\text { professional growth; } \\
\text { - an increase in the proportion of } \\
\text { employees who expressed satisfaction } \\
\text { with the opportunities for career growth; } \\
\text { - decrease in the level of employee } \\
\text { turnover due to dissatisfaction with the } \\
\text { opportunities for career development; } \\
\text { - increase in the proportion of employees } \\
\text { who expressed a positive attitude to the } \\
\text { project, supporting changes; } \\
\text { - increase in the proportion of employees } \\
\text { expressing satisfaction with the } \\
\text { conditions for self-expression } \\
\text { - Increase in the proportion of employees } \\
\text { who expressed satisfaction with the } \\
\text { reward system }\end{array}$} \\
\hline & $\begin{array}{l}\text { Improving the competitiveness of } \\
\text { staff }\end{array}$ & \\
\hline & $\begin{array}{l}\text { Providing employees with the } \\
\text { necessary information and career } \\
\text { opportunities }\end{array}$ & \\
\hline & $\begin{array}{l}\text { Providing opportunities for personal } \\
\text { development of employees }\end{array}$ & \\
\hline & $\begin{array}{l}\text { Forming a sense of employee } \\
\text { participation in the organization }\end{array}$ & \\
\hline \multirow{2}{*}{$\begin{array}{l}\text { Scoring } \\
\text { system }\end{array}$} & $\begin{array}{l}\text { Ensuring a link between } \\
\text { performance and remuneration }\end{array}$ & \multirow{2}{*}{$\begin{array}{l}\text { - increase the cohesion of the collective; } \\
\text { - increase of interest to work; } \\
\text { - increase of initiative of employees }\end{array}$} \\
\hline & $\begin{array}{l}\text { Encouraging the increase of } \\
\text { professionalism and professional } \\
\text { competence }\end{array}$ & \\
\hline
\end{tabular}

\section{Conclusions}

Thus, despite some kind of "closeness" of the Department to maintain the competitiveness of employees and the organization development, it is necessary to introduce management innovations which often do not require over-expenditure and do not contradict the provisions governing the activities of the Department.

\section{References}

1. S.V. Shekshnja, Upravlenie personalom sovremennoj organizacii. Uchebnoprakticheskoe posobie. 5-e izd. pererab. i dop (Intel-Sintez, Moscow, 2002) 
2. E. Avdeeva, T. Averina, L. Kochetova, E3S Web of Conference, 03013 (2018)

3. S. Belyaeva, O. Belyantseva, N.Safonova, O. Vasilyeva, E3S Web of Conferences, 03021 (2018)

4. T.A. Averina, Jekonomika i menedzhment sistem upravlenija 9(3.1), 130-136 (2013)

5. L.S. Grebnev, Jekonomika (Logos, Moscow, 2011) http://www.biblioclub.ru/index.php?page=book\&id=84982

6. E.A. Avdeeva, Jekonomika i menedzhment sistem upravlenija 7(1.1), 124-134 (2013)

7. D.L. Kirkpatrick, J.D. Kirkpatrick, Evaluating training programs: the four levels (3rd ed.) (Berrett- Koehler, San Francisco, 2006)

8. V.V. Gluhov, Innovacionnoe razvitie jekonomiki megapolisa: Uchebnoe posobie (Lan', $\mathrm{SPb}, 2010)$

9. D.A. Novikov, A.A. Ivashhenko, Modeli $i$ metody organizacionnogo upravlenija innovacionnym razvitiem firmy (LENAND, Moscow, 2006)

10. S.A. Barkalov, T.A. Averina, Radio Electronics 16(2), 82-90 (2016)

11. T.A. Averina, Jekonomika i menedzhment sistem upravlenija 4.3(6), 300-305 (2012)

12. O.S. Perevalova, Upravlenie stroitel'stvom 1(9), 68-73 (2017) 